\title{
Effect of cyanide intoxication on the metachromatic material found in the central nervous system
}

\author{
M. Z. M. IBRAHIM ${ }^{1}$ AND SEYMOUR LEVINE \\ From the Pathology Department, New York Medical College Center for Chronic Disease, \\ Bird S. Coler Hospital Division, Welfare Island, New York, and Ames Research Center, NASA, \\ Moffett Field, California
}

In the course of studies on the rat brain, tissue was fixed in formalin-alcohol. Frozen sections stained with toluidine blue revealed numerous $\gamma$-metachromatic bodies (MB), mainly in relation to myelin. These bodies were felt to be a product of fixation (artifact) probably caused by the solution of some myelin component and its reprecipitation mainly within the white matter. Similar bodies have been described previously but there is no uniformity of opinion as to their origin, chemical nature, or significance (Ferraro, 1928; Grinker and Stevens, 1929; Smith, 1949; Wislocki and Singer, 1950; Wolman, 1960). The close relationship to, and probable derivation from, myelin suggested that analysis of the chemical structure of the metachromatic bodies in normal rat brain might increase our understanding of myelin. Also a close similarity appeared to exist between them and the material found inside the 'mucocytes' described by Grinker and Stevens (1929) and possibly the mucoid substance in the cytoplasm of swollen oligodendrocytes. Lastly, we thought that any early pathological change in myelin might be reflected and perhaps magnified in the metachromatic bodies. With this in mind, we studied the metachromatic bodies in the white matter lesions of cyanide-poisoned rats.

\section{MATERIALS AND METHODS}

Thirty-four predominantly young adult Lewis rats of both sexes with a minimum body weight of about $220 \mathrm{~g}$. were used. These were divided into two groups. (1) Seven rats were not subjected to any experimental procedure and were used as normal controls. Four of these were anaesthetized with chloroform and killed by exsanguination. The fifth was killed rapidly with ether, the sixth was kept anaesthetized with ether for five minutes, when it was killed also by the ether, and the last was anaesthetized with intraperitoneal sodium nembutal $(2.5 \mathrm{mg} . / 100 \mathrm{~g}$.

${ }^{1}$ National Research Council postgraduate resident research associate supported by the National Aeronautics and Space Administration. Supported by U.S. Public Health Service grant no. MH-11698-01. body weight) for 30 minutes and then killed by an overdosage of nembutal. These animals were included in the study to assess whether narcosis or the mode of killing had any effect on the appearance or distribution of the metachromatic bodies. No such effect was found. (2) Twenty-seven rats were exposed for 20 to 30 minutes to $\mathrm{HCN}$ gas according to the 'static method' of Levine (1960). These were killed after varying intervals of time ranging from directly after exposure (usually by overdosage of $\mathrm{HCN}$ at the end of $30 \mathrm{~min}$.) up to 80 days. The brains of animals killed directly after exposure and up to one week after exposure are described in this communication. The rest of the brains were fixed in Cajal's formalin ammonium bromide $(2 \%$ ammonium bromide in $15 \%$ formalin(F.A.B.)) and used for a separate neuroglial study.

Most of the animals were anaesthetized with ether and killed by exsanguination and their brains promptly removed and processed for the demonstration of neuroglia (Ibrahim, Briscoe, Bayliss, and Adams, 1963) and myelin lipids (Adams, 1965). Some whole brains and some slices from most other brains were fixed in $5 \%$ formalin in $80 \%$ ethyl alcohol for a minimum of two days before they were cut on the freezing microtome and examined. The cytological methods were the same as described previously (Ibrahim et al., 1963). Only tissues fixed in $80 \%$ ethanol and tissues fixed for a long time in $10 \%$ formalin and formol-calcium (1\% calcium acetate in $10 \%$ formalin) contained a product of fixation (artifact) resembling that found in formalin-alcohol-fixed blocks. The two artifacts were compared histochemically.

The histochemical methods employed were mainly taken from the schemata given by Adams (1965). They will be referred to under Results. However, the methods employed for examining metachromic phenomena will be mentioned here since there is still disagreement concerning the methodology and its interpretations (see Pearse, 1960, for a discussion of the problem).

Formalin-alcohol-fixed blocks were washed well in water, and frozen sections $20 \mu$ thick were cut and collected in water. These were washed for about 30 minutes, since too large a trace of fixative hampers staining. The sections were placed on slides previously dipped in warm chromegelatin $(0.05 \%$ chromium potassium sulphate in $2 \%$ gelatin) and dried at room temperature. The sections 545 
were gently blotted dry as leaving sections to dry in air seemed to change the stainability of the metachromatic bodies. This might be due to oxidation of the lipid components by atmospheric oxygen (Wolman, 1956a; Adams, 1965). Staining was done with many reagents, but principally with $0.1 \%$ toluidine blue 0 in $30 \%$ ethanol at a $\mathrm{pH}$ of 4.5 for 10 to 15 minutes, and also $0.1 \%$ azure $A$. The sections were then taken out, washed in distilled water, blotted dry, and dehydrated in absolute ethanol, in which they could be kept up to two minutes before the metachromatic bodies started to fade. Sections from formalin-fixed blocks resisted fading very poorly, however. The $\gamma$-metachromasia of the myelin sheaths also disappeared almost immediately. The sections were then cleared in xylol, in which the formalin-alcohol tissue could be left safely for some time. They were mounted in Canada balsam. The preparations fixed in formalin-alcohol have been found to maintain most of their original colours for months provided the stain was intense before dehydration.

Formalin-alcohol fixation did not cause qualitative changes in stainability of the different myelin lipid components, but when compared with formalin fixation, some diminution in staining was noted. This was especially noted in the OTAN, NaOH-OTAN, and gold hydroxamate methods; the PAN and modified P.A.S. methods were apparently unaffected (see Table I). Alcohol fixation gave the same results as formalin-alcohol fixation except that the number of metachromatic bodies was much smaller and all lipids were poorly preserved; therefore, no further reference will be made to alcohol-fixed material.

\section{RESULTS}

OCCURRENCE, DISTRIBUTION, AND APPEARANCE OF THE METACHROMATIC BODIES IN NORMAL BRAIN Metachromatic bodies were found both in formalinalcohol-fixed and old formalin-fixed tissues. They were not seen in tissues recently fixed in formalinsaline or in formol-calcium, nor were they seen at all in the F.A.B.-fixed material. Also, the longer the fixation time the larger was the number of metachromatic bodies in the same site up to a certain limit. They were predominantly found in the white matter; the larger the amount of white matter at any given site, the more numerous were the metachromatic bodies, e.g., in the corpus callosum (Fig. 1) and in the white columns of the spinal cord. They were sparse in the grey matter and occurred only in areas where there was a good admixture of myelinated fibres, e.g., at the junction of callosal radiation with cortical grey matter and reticular formation of the brainstem.

The metachromatic bodies of the formalinalcohol-fixed tissue varied somewhat in shape and size (about 30-100 $\mu$ ) and were rounded or oval with a slightly irregular contour. Each was homogeneous and appeared to cause mechanical pressure

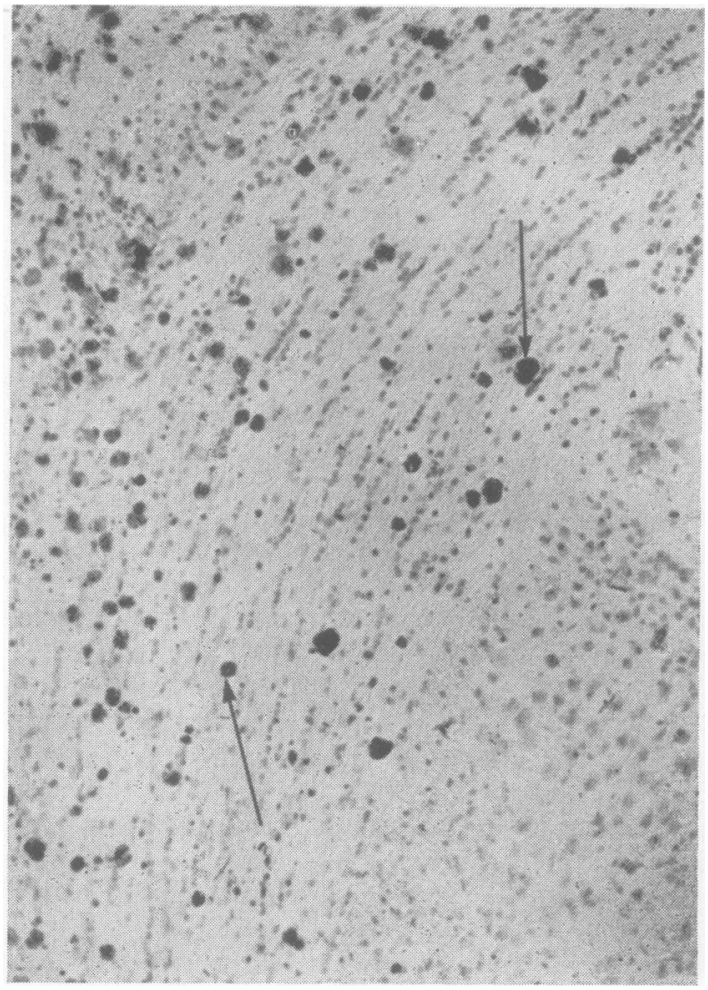

FIG. 1. Metachromatic bodies in normal corpus callosum and callosal radiation. Some stain more heavily than others (arrows). Toluidine blue, $\times 120$.

on its immediate surroundings. Very small ones (30 $\mu$ or less) were rare and were found mainly at the junction of the corpus callosum with callosal radiations.

Sometimes, after long fixation in alcohol-formalin, formalin-saline, and formol-calcium, there were structures that seemed identical with the grape-like bodies described by some authors and commented on by Ferraro (1928) as being different from oligodendroglial mucocytes (see Discussion). The morphology of the metachromatic bodies of formalin-fixed tissue differed from that of the formalinalcohol-fixed in that the former were more numerous, smaller, and more uniform in size.

METACHROMATIC BODIES IN BRAINS FROM CYANIDEINTOXICATED RATS ${ }^{1}$ The changes in the metachromatic bodies from formalin-alcohol-fixed tissue were of two types.

Complete disappearance This occurred in the

${ }^{1}$ For a more comprehensive description of the lesions and a discussion of their aetiology see Ferraro (1933), Levine and Stypulkowski (1959), and Ibrahim et al. (1963). 
centres of necrotic lesions one to two days after exposure (Fig. 2) or in well-established demyelinative lesions from four days after exposure (Fig. 3).

Appearance of the small metachromatic bodies Smaller forms were noted in regions where both proliferation and hypertrophy of oligodendroglia were taking place (see Figs. 3, 4, and 6; compare with Figs. 1 and 5). On close examination, most of these bodies were found not to be related to the nucleus cr the perikaryon, although a few could be seen within the confines of swollen oligodendroglia (Fig. 7). These latter cells were regarded as acutely swollen and closely resembled the 'mucocytes' described by Grinker and Stevens (1929). The material inside these cells differed from the extracellular metachromatic bodies in that it stained much more faintly with basic aniline dyes. Hypertrophied oligodendroglia contained large nuclei surrounded by copious perikaryal cytoplasm that stained very faintly pink. The perikarya of these

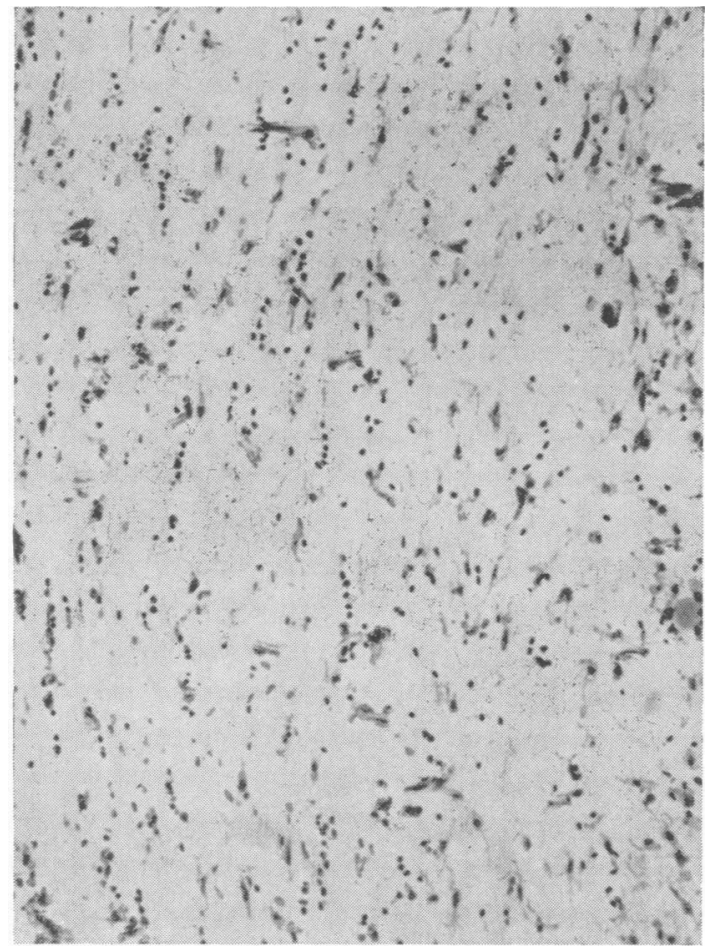

FIG. 2 cells showed no obvious ove-distension. In such areas, microglia were numerous and hypertrophied. The astrocytes were also hypertrophied but only in regions bordering on 'normal' brain substance. In some areas, the oligodendrocytes were proliferated and numerous mitotic figures were seen (Fig. 8), but there were no metachromatic bodies at all. However, in such instances, signs of degeneration in these cells had already started to appear. In areas not showing neurological changes the larger metachromatic bodies were unchanged.

The changes observed in the metachromatic bodies from formalin-fixed tissue closely resembled those just described for those from formalinalcohol-fixed tissue, but the appearance of smaller forms in proliferative areas was accompanied by a diffuse stain in the background, unrelated to any cellular structure.

\section{HISTOCHEMISTRY OF METACHROMATIC BODIES These}

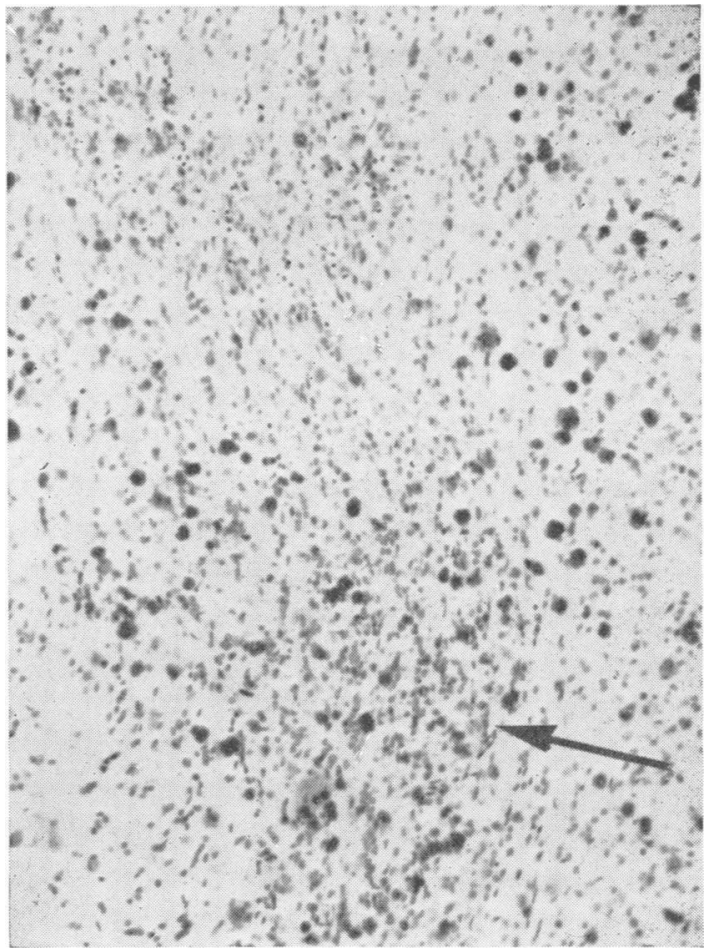

FIG. 3

FIG. 2. Early necrotic lesion in corpus callosum (24 hours after exposure). Note absence of metachromatic bodies, presence of pyknotic nuclei, general disorder, and relative rarefaction, especially in the centre. Toluidine blue, $\times 120$.

FIG. 3. Marked increase in neuroglial population in corpus callosum (proliferative lesion; four days after exposure). Numerous small metachromatic bodies, although not prominent, can be seen, especially in the region of the arrow where cellular population is densest. Large bodies are also present. Toluidine blue, $\times 120$. 


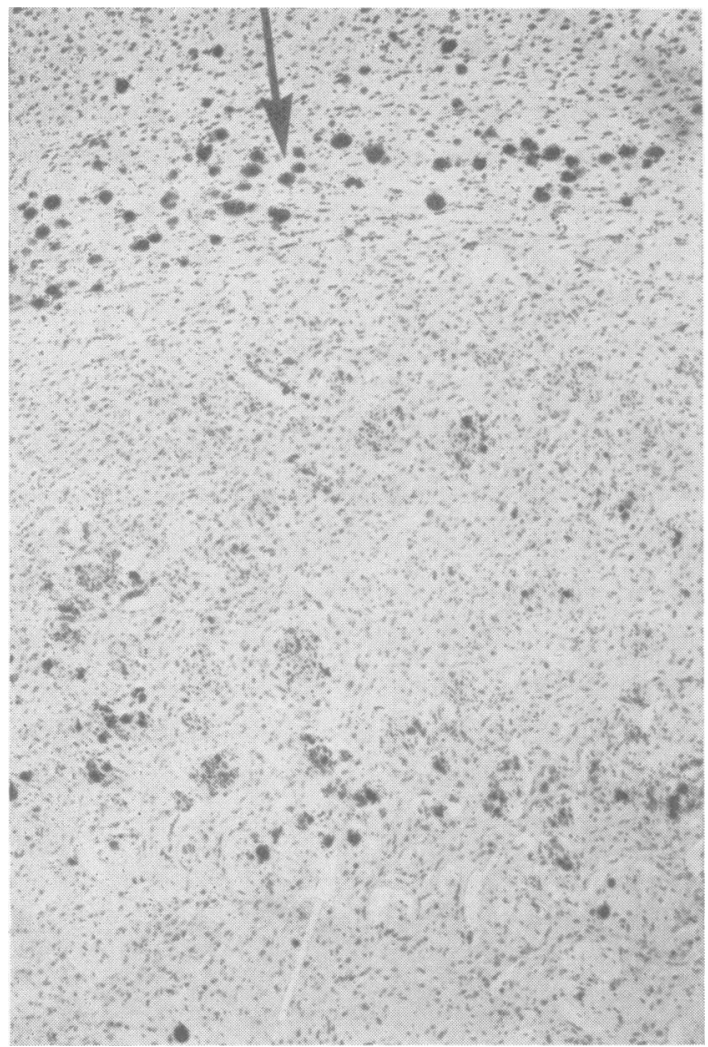

FIG. 4

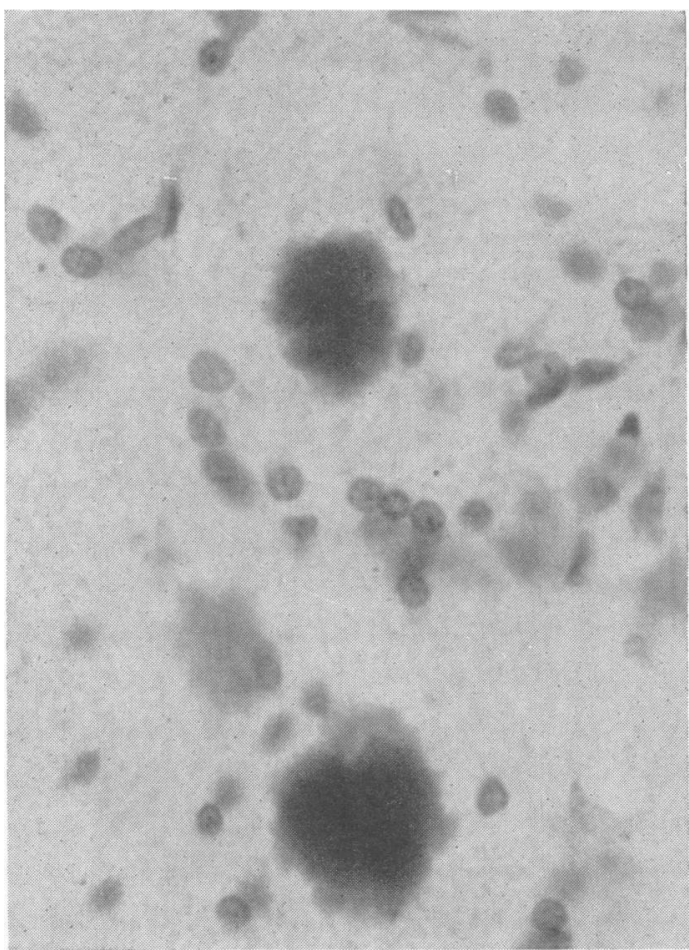

FIG. 5

FIG. 4. Proliferative lesion (one week after exposure) in corpus striatum bounded on one side by callosal radiation (black arrow). Both this and the edge in the centre of the corpus striatum (white arrow) show numerous metachromatic bodies. White matter 'islands' show cellular proliferation throughout, but centrally they do not generally contain metachromatic bodies. Toluidine blue, $\times 52$.

FIG. 5. Normal white matter 'islands' in corpus striatum with single large metachromatic bodies from alcohol-formalin-stained tissue. Toluidine blue, $\times 625$.

FIG. 6. An 'island' showing marked proliferation and hypertrophy of oligodendroglial nuclei (one week after exposure). Many small metachromatic bodies from formalin-alcohol-stained tissue can be seen but there is no obvious relationship to the nuclei. Toluidine blue, $\times 760$.

FIG. 6 


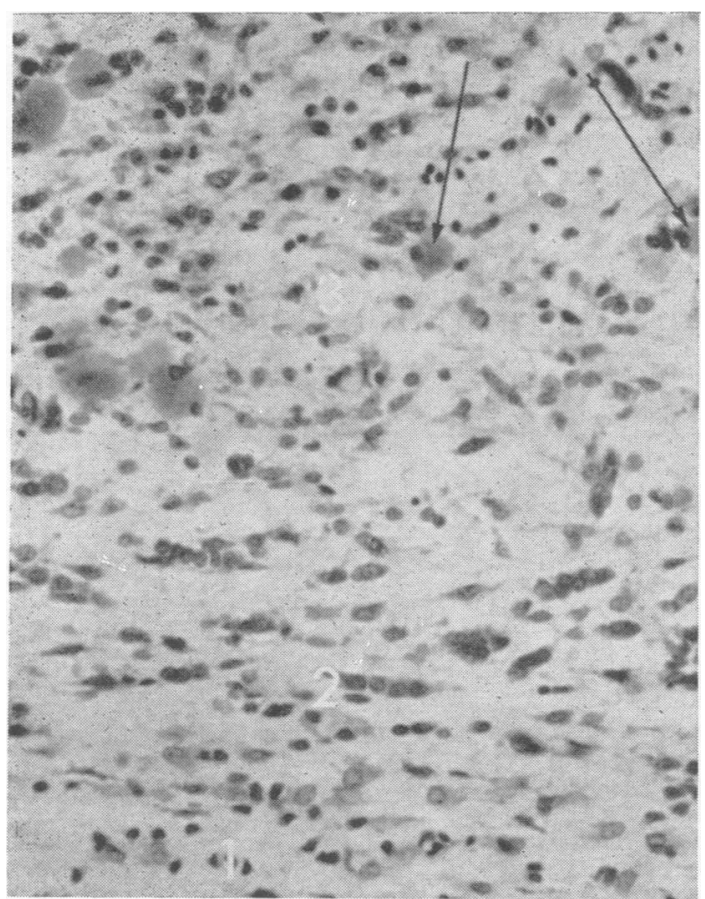

FIG. 7

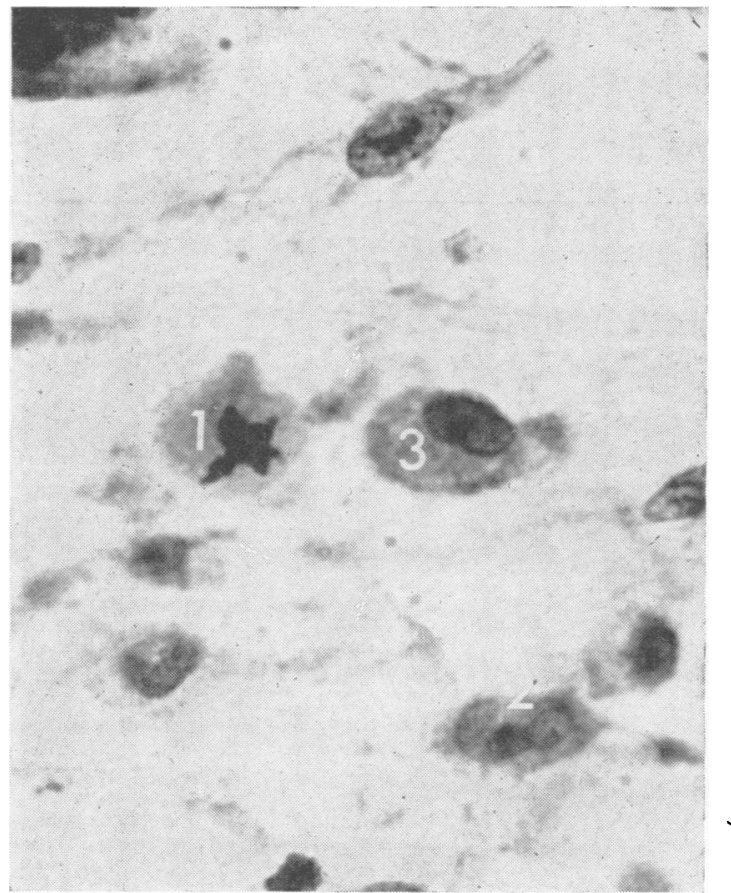

FIG. 8

FIG. 7. Early demyelinating lesions of corpus callosum (three days after exposure). (I) 'Normal' zone, (2) zone of neuroglial hypertrophy and proliferation, (3) central zone showing pyknotic nuclei and some very small metachromatic bodies from formalin-alcohol-fixed tissue closely related to oligodendroglial nuclei (arrows). Toluidine blue, $\times 250$.

FIG. 8. Edge of a demyelinating lesion (five days after exposure) showing (1) a mitotic figure, (2) a hypertrophied astrocyte, and (3) a swollen, hypertrophied oligodendrocyte. Toluidine blue, $\times 1,000$.

results are presented in Table $I$. The morphologically altered bodies in cyanide lesions gave the same reactions as those in normal brain.

\section{DISCUSSION}

Mucopolysaccharides have been demonstrated histochemically in both the peripheral and central nervous systems (Abood and Abul-Haj, 1956; Brante, 1957 and 1959; Young and Abood, 1960; Wolman, 1956b, 1957, 1960; Wolman and HestrinLerner, 1960). Szabo and Roboz-Einstein (1962), Balasubramanian and Bachhawat (1964), and Singh and Bachhawat (1965) identified mucopolysaccharides chemically in the central nervous system. The latter authors concluded that in the sheep brain hyaluronic acid and chondroitin-4-sulphate (chondroitin sulphate A) predominate, while heparin and chondroitin-6-sulphate (chondroitin sulphate C) are found in smaller amounts. Still smaller amounts of hyaluronidase-resistant dermatan sulphate (chondroitin sulphate B) or heparin (heparitin) sulphate or both are also detectable. In this connexion, heparin has been found to be sulphated in varying degree (from one to three sulphate radicles per disaccharide unit). The less sulphated form (heparin sulphate) is moderately P.A.S. positive and shows metachromasia. The more heavily sulphated is metachromatic but P.A.S. negative (Jorpes. Werner and Åberg, 1948; Barka and Anderson, 1963). Singh and Bachhawat also found that, in general, white matter is richer in hyaluronic acid than in sulphated mucopolysaccharides, which are more abundant in grey matter.

CHEMICAL IDENTITY OF METACHROMATIC BODIES FROM FORMALIN-ALCOHOL-FIXED TISSUE The results as shown in the Table indicate the possible presence of acidic mucopolysaccharides in metachromatic bodies from tissue fixed with formalin-alcohol, e.g., the basic aniline dyes stained the bodies metachromatically at very low $p \mathrm{H}$, indicating their acidic nature. With Wolman's (1961) Bi-Col method, they stained blue. To colloidal iron they were very 
TABLE I

IDENTIFICATION OF THE CHEMICAL NATURE OF THE METACHROMATIC BODIES ${ }^{1}$

\begin{tabular}{|c|c|c|c|}
\hline \multirow[b]{2}{*}{ Stain } & \multirow[b]{2}{*}{ Substance Stained and Specificity of Method } & \multicolumn{2}{|c|}{ Motachromx'ic Bodies fro $m$} \\
\hline & & $\begin{array}{l}\text { Formalin-alcohol- } \\
\text { fixed Tissue }\end{array}$ & $\begin{array}{l}\text { Formalin- } \\
\text { fixed Tissue }\end{array}$ \\
\hline Sudan black & $\begin{array}{l}\text { Most unsaturated lipids, glycolipids, and phospholipids } \\
\text { (non-specific, but stains only lipids) }\end{array}$ & + & - \\
\hline Oil red $\mathbf{O}$ & $\begin{array}{l}\text { Neutral lipids and fatty acids give specific intense red colour but } \\
\text { the non-specific colour for other lipids is pale red }\end{array}$ & Pale red & - \\
\hline Luxol fast blue & $\begin{array}{l}\text { On frozen sections. Probably stains lipids but possibly proteins } \\
\text { as well }\end{array}$ & + & - \\
\hline OTAN & $\begin{array}{l}\text { Unsaturared phospholipids (cerebroside weakly) red-brown; } \\
\text { hydrophobic unsaturated lipids are black (fairly specific) }\end{array}$ & Pale brown & - \\
\hline $\mathrm{NaOH}$ and OTAN & $\begin{array}{l}\text { Sphingomyelin and other alkali-stable phospholipids are } \\
\text { red-brown (fairly specific) }\end{array}$ & Pale brown & - \\
\hline $\begin{array}{l}\text { Perchloric acid } \\
\text { naphthoquinone (PAN) }\end{array}$ & $\begin{array}{l}\text { Cholesterol, desmosterol, and cholesterol esters; blue (specific) } \\
\text { and cerebroside; brown (fairly specific). Light brown colour } \\
\text { probably indicates burnt lipid }\end{array}$ & (Light brown) - & (Very light brown)- \\
\hline Gold hydroxamate & $\begin{array}{l}\text { Phosphoglycerides (lecithins and cephalins) are stained reddish } \\
\text { brown (specific) }\end{array}$ & (Pale grey) - & - \\
\hline Modified P.A.S. & $\begin{array}{l}\text { Cerebroside and protein-bound ganglioside (prevented by } \\
\text { preliminary lipid extraction with chloroform-methanol) } \\
\text { (fairly specific) }\end{array}$ & Strongly + & A aidir but Sula \\
\hline Nile blue sulphate & $\begin{array}{l}\text { Phospholipids and sulphatide are stained blue; hydrophobic } \\
\text { lipids are pink (fairly specific) }\end{array}$ & Blue & $\begin{array}{l}\text { Acidic_but Sudan } \\
\text { black-(therefore } \\
\text { not lipid) }\end{array}$ \\
\hline Alcian blue at low $p H(2 \cdot 0)$ & $\begin{array}{l}\text { Strongly acidic groups (sulphatide, A.M.P.S. and linoleic acid) } \\
\text { (both frozen and surviving bodies in paraffin) (specific) }\end{array}$ & $(20 \mathrm{~min})+$. & + but less strongly \\
\hline $\begin{array}{l}\text { Alcian blue- } \\
\text { Safranin }(p \mathrm{H} 1.5)\end{array}$ & $\begin{array}{l}\text { Weakly sulphated-orange, strongly sulphated mucopoly- } \\
\text { saccharides-blue (?specificity) }\end{array}$ & Orange & Blue \\
\hline $\begin{array}{l}\text { Alcian blue }+0.7 \\
\text { or } 1.0 \mathrm{M} \text { magnesium } \\
\text { chloride at } p \mathrm{H} 2\end{array}$ & $\begin{array}{l}\text { Alcianophilia with } 1.0 \mathrm{M}-\mathrm{Mg} \mathrm{Cl}_{2}-\text { heparin, keratan sulphate } \\
\text { Alcianophilia with } 0.7 \mathrm{M}-\mathrm{Mg} \mathrm{Cl}_{2}-\text { dermatan sulphate } \\
\text { (?specificity) }\end{array}$ & $\stackrel{+}{\text { Stronger }+}$ & $\begin{array}{l}\text { Weak }+ \\
+\end{array}$ \\
\hline $\begin{array}{l}\text { Methylene blue } \\
\text { extinction }\end{array}$ & $\begin{array}{l}\text { If nucleic acids (and lipid complexes, e.g., lipochondria) are } \\
\text { excluded staining below } p \mathrm{H} 2 \text { indicates A.M.P.S. or sulphatide } \\
\text { (specific) }\end{array}$ & Below pH 2.0 & pH 2.0 \\
\hline $\begin{array}{l}\text { Toluidine blue and } \\
\text { Azure A }\end{array}$ & $\begin{array}{l}\text { Red }(\gamma) \text { metachromasia (mounting in water) indicates strongly } \\
\text { acidic groups }\left(\mathrm{SO}_{4} \text { or } \mathrm{PO}_{4} \pm \mathrm{COOH}\right) \text { (specific) }\end{array}$ & + & + but less intense \\
\hline $\begin{array}{l}\text { Tol. blue-saturated with } \\
\text { magnesium chloride }\end{array}$ & $\begin{array}{l}\text { Strongly sulphated mucopolysaccharide, e.g., most mast cells } \\
\text { and cartilage (specific) }\end{array}$ & - & - \\
\hline $\begin{array}{l}\text { Colloidal iron } \\
\text { (Müller-Mowery) }\end{array}$ & $\begin{array}{l}\text { Strongly acidic groups (A.M.P.S., sulphatide and some } \\
\text { phospholipids) (on surviving bodies in paraffin sections) (specific) }\end{array}$ & Strongly + & Strongly + \\
\hline Wolman's Bi-col method & $\begin{array}{l}\text { Weakly acidic substances-reddish brown, strongly acidic } \\
\text { (PO, or } \mathrm{SO}_{4} \text {-bluish (specific) }\end{array}$ & Blue & Reddish brown \\
\hline $\begin{array}{l}\text { Cresyl violet-acetic acid } \\
\text { and thionin-acetic }\end{array}$ & Brown metachromasia indicates sulphatides (specific) & $\begin{array}{l}+ \text { but rest of myelin } \\
\text { can be brownish, too }\end{array}$ & $\begin{array}{l}\text { Very pale brown in } \\
\text { most, uncoloured in } \\
\text { some }\end{array}$ \\
\hline $\begin{array}{l}\text { Holländer's method for } \\
\text { sulphatides, light micro- }\end{array}$ & $\begin{array}{l}\text { Sulphatides (specific provided presence of A.M.P.S. (sulphated) } \\
\text { is excluded) }\end{array}$ & + & 一 \\
\hline $\begin{array}{l}\text { scopy, Holländer's method } \\
\text { fluorescence microscopy }\end{array}$ & $\begin{array}{l}\text { Sulphatides (specific provided presence of A.M.P.S. (sulphated) } \\
\text { is excluded) }\end{array}$ & Iight & $\begin{array}{l}+ \text { but somewhat less } \\
\text { intense }\end{array}$ \\
\hline $\begin{array}{l}\text { Haematoxylin } \\
\text { Paraffin embedding after } \\
\text { chloroform or xylol }\end{array}$ & Acidic groups (specific) & $\begin{array}{l}\text { Light }+ \\
\text { Almost all bodies } \\
\text { gone leaving empty } \\
\text { holes }\end{array}$ & $\bar{M}$ ost bodies preserved \\
\hline P.A.S. on frozen sections & (Non-specific) & + like rest of myelin & Weakly + \\
\hline P.A.S. on paraffin sections & (Non-specific) & $\begin{array}{l}\text { Strongly }+ \text { if not } \\
\text { dissolved out }\end{array}$ & Weakly + \\
\hline $\begin{array}{l}\text { Modified Molisch's test } \\
\text { Ninhydrin }\end{array}$ & $\begin{array}{l}\text { Carbohydrate (of glycolipids) (?specificity) } \\
\text { Amino acids, polypeptides, and proteins (specific) }\end{array}$ & \pm & 二 \\
\hline Millon's reaction & $\begin{array}{l}\text { Tyrosine (for proteins in general and protein in relation to } \\
\text { glyco- or muco-proteins) (specific, but weak) }\end{array}$ & - & - \\
\hline $\begin{array}{l}\text { Morel-Sisley } \\
\text { diazotization }\end{array}$ & Tyrosine (specific) & - & - \\
\hline $\begin{array}{l}\text { DMAB-nitrite } \\
\text { Einarson's gallocyanin }\end{array}$ & Indoles (specific). Tryptophan gives strong reaction (non-specific) & - & - \\
\hline $\begin{array}{l}\text { Einarson's gallocyanin } \\
\text { Diastase and } \alpha \text {-amylase } \\
+ \text { (P.A.S.) }\end{array}$ & $\begin{array}{l}\text { D.N.A. and R.N.A. (specific) } \\
\text { Glycogen (liver as control) (specific) }\end{array}$ & $\begin{array}{l}\text { Fast (normal myelin } \\
\text { less intense) }\end{array}$ & 二 \\
\hline $\begin{array}{l}\text { Hyaluronidase } \\
\text { (bovine testicular) }\end{array}$ & $\begin{array}{l}\text { Removes hyaluronic acid and chrondroitin sulphates } A \text { and } \\
\text { C (A.M.P.S.) }\end{array}$ & Fast & Fast \\
\hline
\end{tabular}

Motachromx'ic Bodies fro $m$

(non-specific, but stains only lipids)

Neutral lipids and fatty acids give specific intense red colour but

as well red-brown (fairly specific)

Cholesterol, desmosterol, and cholesterol esters; blue (specific) and cerebroside; brown (fairly specific). Light brown colour brown (specific)

Cerebroside and protein-bound ganglioside (prevented by ( (airly specific)

Phospholipids and sulphatide are stained blue; hydrophobic

Strongly acidic groups (sulphatide, A.M.P.S. and linoleic acid) (specific) saccharides-blue (?specificity)

Alcianophilia with $1.0 \mathrm{M}-\mathrm{Mg} \mathrm{Cl}_{2}-$ heparin, keratan sulphate

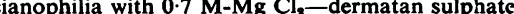
?specificity)

If nucleic acids (and lipid complexes, e.g., lipochondria) are (specific)

Red $(\gamma)$ metachromasia (mounting in water) indicates strongly Strongly acidic groups (A.M.P.S., sulphatide and some (on surviving bodies in paraffin sections) (specific) Weakly acidic substances-reddish brown, strongly acidic (PO, or SO 4 -bluish (specific)

Pale red

Pale brown

Pale brown

HCN, hydrogen cyanide; A.M.P.S., acid mucopolysaccharide.

${ }^{1}$ Methods mainly after Adams (1965). 


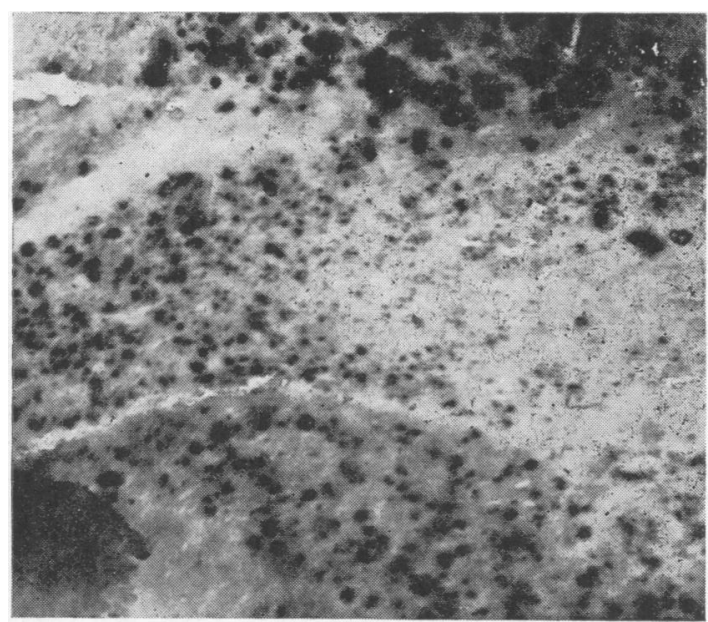

FIG. 9. Both large and small metachromatic bodies from formalin-alcohol-fixed tissue around an established demyelinating lesion (one week after exposure) in the corpus callosum where no metachromatic bodies are seen in the centre. Modified P.A.S. method for glycolipids, $\times 100$.

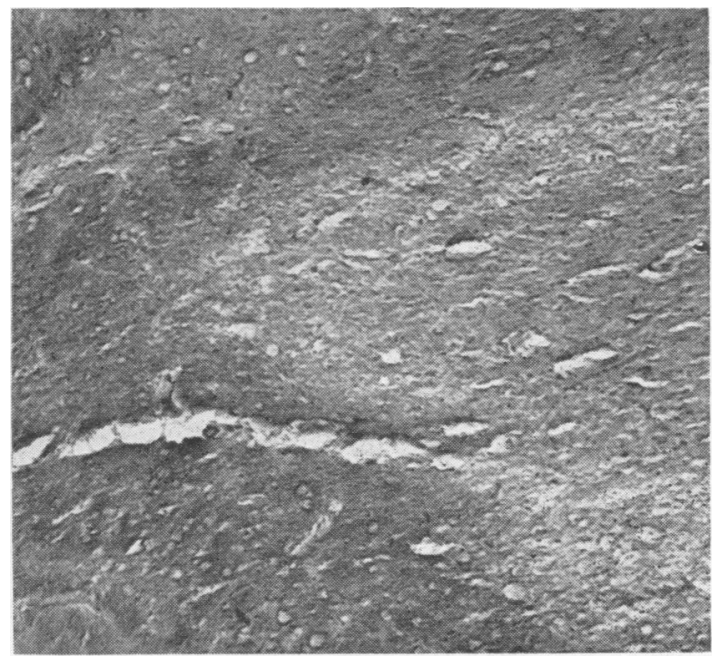

FIG. 10. Same as Fig. 9, but after chloroform-methanol extraction. The metachromatic bodies appear as empty holes. Modified P.A.S. method, $\times 100$.

strongly positive, again indicating their acidic nature. However, they stained with alcian blue but only after a long time, and with the alcian bluesafranin method they became orange and not blue (Spicer, Leppi, and Stoward, 1965) indicating that their acidity is not very strong. Such acidity is attributed to phosphate or more usually to sulphate groupings, and the positive colour obtained with Holländer's method would support the presence of such acidic sulphate groupings (see later discussion of this method).

Although the presence of such strongly acidic sulphate groupings seems certain, the presence of the mucopolysaccharide does not, on closer examination, seem so certain. The presence of lipid material is definite: the general lipid stains-sudan black, oil red $\mathrm{O}$, and luxol fast blue on frozen sectionsgive positive results. The latter method, even though carried out on frozen sections, probably stains proteins as well; in paraffin sections this stain probably demonstrates only proteins. The more specific Nile-blue sulphate and the modified P.A.S. method also give positive results (Figs. 9 and 10). The first method indicates that the lipid is acidic, while the latter method demonstrates that it is a glycolipid (cerebroside). The brown metachromasia with the cresyl violet and thionin methods further indicates the presence of sulphatide (see Davison and Gregson, 1962, for specificity of the method). Again, the results obtained with the use of the modified Molisch's method further support the presence of such a glycolipid which would, in all probability, be a cerebroside (and/or sulphatide) since there is hardly any ganglioside in white matter (Brante, 1949, 1957). Such sulphatide can give identical staining properties as a sulphated mucopolysaccharide (see later discussion).

The modified P.A.S. method of Adams, Bayliss, and Ibrahim (1963) demonstrates the presence of cerebrosides and only protein-bound gangliosides, since the free form of the latter is water soluble and is, therefore, lost. This method does not, however, demonstrate the presence of the sulphated form of cerebroside. (The sulphate moiety is linked to carbon atom 3 in the galactose molecule of the cerebroside (see Brady and Trams, 1964; Carter, Johnson, and Weber, 1965; Adams, 1965); thus, the 1,2-glycol configuration of this sugar is not available for oxidation by periodic acid and, hence, sulphatides are P.A.S.-negative.) Chloroformmethanol extraction applied to control sections in this method removes not only cerebrosides, other lipids, and lipoproteins, but can also conceivably remove mucopolysaccharide if firmly bound to such substances. Such extraction does not remove P.A.S.-positive neutral mucopolysaccharides. As seen in the Table, the metachromatic bodies from formalin-alcohol-fixed tissue did stain positively and chloroform-methanol completely extracted them. Therefore, one would be justified in concluding that these 'bodies' contain cerebroside, but 
one cannot, by this method, rule out the presence of extractable acid mucopolysaccharides.

Höllander's $(1963,1965)$ method gave positive results and since the metachromatic bodies from formalin-alcohol-fixed tissue are lipid-extractable (see Adams, 1965), this further supports the presence of sulphatide unless, again, acid mucopolysaccharide is present, firmly bound to the cerebroside and becomes extracted with it.

Concerning the susceptibility of acid mucopolysaccharide to hyaluronidase digestion, Spicer et al. (1965) stated that a sulphated mucopolysaccharide is usually-but by no means alwayssusceptible to hyaluronidase digestion. In this connexion, Singh and Bachhawat (1965) found that both dermatan and heparin sulphates are hyaluronidase-resistant (see above); these substances are present but only in small amounts in white matter. Also, Spicer et al. (1965), as well as Kramer and Windrum (1955), found that only sulphated mucopolysaccharides stain metachromatically and that this metachromasia is also alcohol-resistant. We found that the metachromatic bodies from alcohol-formalinfixed tissue gave an alcohol-labile colour and were hyaluronidase-resistant. Therefore, it would seem that on the whole there is probably no acid mucopolysaccharide in them, although one can by no means be certain of this.

The absence of any demonstrable protein or mucin reactions helps to exclude the possible presence of glycoproteins, mucoproteins, nucleoproteins, or mucins.

Finally, it seems that the presence of a sulphate grouping, a lipid, and a sugar is well documented, but the problem is how these three moieties are bound together. The metachromasia, alcianophilia (weak), blue colour with Wolman's method and the positivity to colloidal iron, would point to the binding of the sulphate radicle to the sugar alone, i.e. acid mucopolysaccharide. This, however, need not be since, as already mentioned, all the same colour reactions can be given by the combination of the sulphate radicle with the sugar-containing lipid, i.e., sulphatide (Wolman, 1961; Adams, 1965).

Therefore, the metachromatic bodies from formalin-alcohol-fixed tissue probably consist of a glycolipid (cerebroside), part of which is sulphated (sulphatide). The presence of an acidic mucopolysaccharide, as well, cannot be ruled out.

CHEMICAL IDENTITY OF METACHROMATIC BODIES FROM FORMALIN-FIXED TISSUE As seen in the Table, the most distinguishing feature of these bodies, as compared with those from formalin-alcohol-fixed tissue, is the absence of any lipid. However, they behave in a similar fashion toward basic aniline dyes (but with less intense colours) indicating their acidic nature and probable content of a moderate amount of sulphate groupings. Wolman's colloidal gold further indicates that their acidity is not great. They are also hyaluronidase-resistant and they stain, but weakly, with alcian blue containing $1 \mathrm{M}$ magnesium chloride and with alcian blue at $p \mathrm{H} 2$. Unlike the bodies from formalin-alcohol-fixed tissue, they are weakly P.A.S.-positive, whether in frozen or paraffin sections. They do not seem to contain any simple or conjugated proteins, nor do they contain any type of mucin.

According to the classification of Spicer et al. (1965), a mucopolysaccharide that is acidic. i.e., stains with acidic alcian blue containing $1 \mathrm{M}$ magnesium chloride, is resistant to testicular hyaluronidase digestion, is of a connective tissue type (as compared with epithelial types), and is not strongly sulphated, would have to be keratan sulphate (keratosulphate), heparin sulphate, or chondroitin sulphate $B$. The presence of keratan sulphate in brain is dubious (Balasubramanian and Bachhawat, 1964) and, hence we are left with a choice between the latter two mucopolysaccharides or perhaps a combination of both. As previously mentioned, heparin sulphate should be P.A.S.-positive and, as the metachromatic bodies are only weakly positive, one can conclude that they mainly contain chondroitin sulphate $B$ and possibly a small amount of heparin sulphate; chondroitin sulphate $B$ is P.A.S.-negative.

On comparing the fixative actions of formalinalcohol and formalin alone, it seems that the presence of alcohol in the fixative is the most likely cause for the precipitation of the glycolipid in the metachromatic bodies. This is rather reminiscent of the action of alcohol on the precipitation and preservation of glycogen (see also Wolman, 1960).

CHEMICAL IDENTITY OF THE OLIGODENDROGLIAL MUCOCYTIC MATERIAL Because of its faint stainability, metachromatic material of swollen oligodendrocytes could not be studied by any of the methods we have employed, and therefore its chemical identity is not clear, although it must be closely related to the metachromatic bodies from formalinalcohol-fixed tissue; some of the P.A.S.-positive material seen in sections stained with the modified P.A.S. method for glycolipids seemed to be within oligodendrocytic plasma membranes.

GENERAL DISCUSSION The histochemical demonstration of metachromasia in normal and pathological peripheral and central myelin is well established but it is a false type of metachromasia, not resisting alcohol treatment (Noback and Montagna, 1952; Noback, 1954; Noback and Reilly, 1956; Pearse, 
1960; Adams, 1965). This speaks against the presence of a strongly acidic mucopolysaccharide. Nevertheless, Wolman (1960) writing on 'The grapelike bodies of the central nervous system' concluded that the 'bodies formed mainly at the expense of ground substance polysaccharide' and do not, on the whole, contain 'any myelin lipids.' Now, although his method of fixation employing alcohol is different from ours, his 'single bodies' are almost identical with our metachromatic bodies. Wolman, however, based his conclusion on studies of paraffin-embedded tissues from which most glycolipid would have dissolved during processing; he did describe the frequent 'cyst-like spaces', which we also saw, in paraffin section. He further concluded that the bodies 'contain strongly acidic (sulphate or phosphate) radicles', and he attributed these to the acidic polysaccharide. We agree with him but only with respect to that part of his material which was fixed in formalin alone. He also excluded the possibility that the bodies are derived from myelin since they appeared in the brain at a stage earlier than that of myelination and in the spinal cord after myelination had begun; he saw them at 18-22 days of postnatal life. This to us does not seem reasonable because myelination, exemplified by cerebroside accumulation dres, in fact, reach its peak at this very age-the beginning of maturation.

The close relationship between the appearance or disappearance of metachromasia in the central nervous system in relation to pathological conditions has already been mentioned by several writers. For instance, acutely swollen oligodendroglia occurring in a variety of conditions were found to contain mucoid, acidic, and metachromatic materials (Ferraro, 1928; Grinker and Stevens, 1929). Greenfield and Meyer (1963), and Russell and Rubinstein (1963) have described such metachromasia in relation to oligodendrogliomas and the former authors mentioned also that this phenomenon is seen in diffuse sclerosis and 'under various conditions, many of which are associated with some degree of demyelination, swollen oligodendrocytes are found to contain a glycolipid resembling cerebroside.' Lumsden (1951) had earlier stated that 'the metachromatic substances present in the leucodystrophies are galactosphingosides or cerebrosides or they may be related to these substances, and that the oligodendrocyte is intimately concerned with the metabolism of these substances.' More recently, Holländer (1965) has suggested the presence of mucopolysaccharides in the cerebroside sulphate ester granules formed in the brains in metachromatic leucoencephalopathy. Furthermore, Ungar, Hine, Kodama, and Anderson (1955), studying the effect of poisoning of rats with p-tertiary butyltoluene, concluded that the metachromatic substance, seen early within glial cells and later only as poorly defined vacuoles, appeared to be a cerebroside and may have been a sulphatide. It seems that in both experimental and pathological damage to myelin, some form of glycolipid (cerebroside, sulphated or otherwise) appears closely related to oligodendroglia; some investigators have included an acidic carbohydrate-containing material (probably acid mucopolysaccharide). Our present results neither support nor disprove such findings since we found that normal healthy myelin contains the glycolipid and also the acidic mucopolysaccharide. Our results suggest, however, that the glycolipid and the polysaccharide are closely related. It should be mentioned here that we do not believe that the 'corpora amylacea' are related to the metachromatic bodies as a product of fixation although they are probably closely related chemically to those from formalinfixed tissue.

It is concluded from the study of the cyanide lesions that changes in myelin metachromatic bodies (in effect representing some chemical components of myelin) take place at an early stage but not earlier than the visible changes in neuroglia, especially olig sdendrocytes. One can also conclude, at least at the light microscope level and with the histochemical means at hand, that oligodendroglial hypertrophy and proliferation in cyanide demyelination occur at least simultaneously with the earliest demonstrable change in myelin (see Ibrahim et al., 1963). In view of the most recent electron microscope findings of Hirano, Levine, and Zimmerman (1967), who employed identical cyanide exposures to ours, such changes would, in fact, be expected to be preceded by the signs of degeneration in axonal and neuroglial processes they described, and might even reflect a reaction to such degenerative changes.

It is worthy of note that the changes in oligodendroglial morphology and number and in central myelin seem to resemble those seen in the Schwann cells and myelin of the peripheral nervous system during Wallerian degeneration, both in the nature of these changes and in their time sequence. In both cases a 'latent period' of three to four days precedes morphological changes in the axons and myelin and numerical changes in the supporting cells whether they be oligodendroglia or Schwann cells (see Abercrombie and Johnson, 1946).

\section{SUMMARY}

Fixation of normal adult rat brain in formalinalcohol caused the artifactual appearance of metachromatically staining bodies in the white matter. 
These bodies, in all likelihood, are caused by the solution and subsequent precipitation of some myelin component by the fixative. They consist of a cerebroside, part of which is sulphated (sulphatide), and possibly also an acidic mucopolysaccharide. Somewhat similar metachromatic bodies were seen in adult brains fixed for long periods in formalin alone; they probably arise in the same manner as the body mentioned above. These latter bodies consist of chondroitin sulphate B (dermatan sulphate) and possibly also a small amount of heparin sulphate. The chemical identification of this second class of bodies represents a direct histochemical demonstration of the presence of an acid mucopolysaccharide in white matter which arises probably from the myelin sheaths. In brains having cyanideinduced lesions, both types of metachromatic body were replaced by more numerous and smaller bodies in relation to areas of oligodendroglial proliferation; they disappeared from necrotic and established demyelinating lesions. It was concluded that oligodendroglial proliferation and hypertrophy are closely related in time to the earliest detectable light microscopic changes in the myelin, exemplified by the metachromatic bodies.

We are indebted to Professor C. W. M. Adams for his guidance and criticisms with special reference to the histochemical aspects of the work and to Dr. Webb Haymaker for revision of the manuscript. We also thank Mrs. Sally Craig for the photographs and Mrs. Irene Burenstein for technical assistance.

\section{REFERENCES}

Abercrombie, M., and Johnson, M. L. (1946). Quantitative histology of Wallerian degeneration. I. Nuclear population in rabbit sciatic nerve. J. Anat. (Lond.), 80, 37-50.

Abood, L. G., and Abul-Haj, S. K. (1956). Histochemistry and characterization of hyaluronic acid in axons of peripheral nerve. J. Neurochem., 1, 119-125.

Adams, C. W. M. (1965). In Neurohistochemistry, pp. 52, 85, 353, edited by C. W. M. Adams. Elsevier, Amsterdam.

- Bayliss, O. B., and Ibrahim, M. Z. M. (1963). Modifications to histochemical methods for phosphoglyceride and cerebroside. J. Histochem. Cytochem., 11, 560-561.

Balasubramanian, A. S., and Bachhawat, B. K. (1964). Enzyme transfer of sulphate from 3'-phosphoadenosine-5'-phosphosulphate to mucopolysaccharides in rat brain. J. Neurochem., 11, 877-885.

Barka, T., and Anderson, P. J. (1963). Histochemistry, p. 72. Hoeber, New York.

Brady, R. O., and Trams, E. G. (1964). The chemistry of lipids. Ann. Rev. Biochem., 33, 75-100.

Brante, G. (1949). Studies on lipids in the nervous system with special reference to quantitative chemical determination and topical distribution. Acta physiol. scand., 18, suppl. 63.

- (1957). Hexosamine compounds in the nervous system. A preliminary report. In Metabolism of the Nervous System, edited by D. Richter, p. 112. Pergamon Press, London.

- (1959). Mucopolysaccharides and mucoids of the nervous system. In Proc. IVth int. Congr. Biochem., Vienna, 1958, Vol 3. Symposium 3. Biochemistry of the Central Nervous System, edited by F. Brücke, p. 291. Pergamon Press, London.

Carter, H. E., Johnson, P., and Weber, E. J. (1965). Glycolipids. Ann. Rev. Biochem., 34, 109-142.
Davison, A. N., and Gregson, N. A. (1962). The physiological role of cerebron sulphuric acid (sulphatide) in the brain. Biochem.J., $85,558-568$.

Ferraro, A. (1928). Acute swelling of the oligodendroglia and grapelike areas of disintegration. Arch. Neurol. Psychiat. (Chic.), 20, 1065-1079.

(1933). Experimental toxic encephalomyelopathy (Diffuse sclerosis following subcutaneous injections of potassium cyanide). Psychiat. Quart., 7, 267-283.

Greenfield, J. G., and Meyer, A. (1963). General pathology of the nerve cell and neuroglia. In Greenfield's Neuropathology, 2nd ed., by W. Blackwood, W. H. McMenemey, A. Meyer, R. M. Norman, and D. S. Russell, p. 56. Arnold, London.

Grinker, R. R., and Stevens, E. (1929). Mucoid degeneration of the oligodendroglia and the formation of free mucin in the brain. Arch. Path., 8, 171-179.

Hirano, A., Levine, S., and Zimmerman, H. M. (1967). Experimental cyanide encephalopathy: Electron microscopic observations of early lesions in white matter. J. Neuropath. exp. Neurol., 26, 200-213.

Holländer, H. (1963). A staining method for cerebroside-sulfuric esters in brain tissue. J. Histochem. Cytochem., 11, 118-119.

- (1965). The histochemical demonstration of mucopolysaccharides in sulphatide granules formed during the intracellular storage of cerebroside sulphate esters (in German, with English summary). J. Neurochem., 12, 335-337.

Ibrahim, M. Z. M., Briscoe, P. B., Jr., Bayliss, O. B., and Adams, C. W. M. (1963). The relationship between enzyme activity and neuroglia in the prodromal and demyelinating stages of cyanide encephalopathy in the rat. J. Neurol. Neurosurg. Psychiat., 26, 479-486.

Jorpes, J. E., Werner, B., and Åberg, B. (1948). The fuchsin-sulfurous acid test after periodate oxidation of heparin and allied polysaccharides. J. biol. Chem., 176, 277-282.

Kramer, H., and Windrum, G. M. (1955). The metachromatic staining reaction. J. Histochem. Cytochem., 3, 227-237.

Levine, S. (1960). Influence of body temperature and size on experimental cyanide encephalopathy. Exp. Neurol., 2, 261-270.

- and Stypulkowski, W. (1959). Experimental cyanide encephalopathy. Arch. Path., 67, 306-323.

Lumsden, C. E. (1951). Fundamental problems in the pathology of multiple sclerosis and allied demyelinating diseases. Brit. med. $J ., 1,1035-1043$.

Noback, C. R. (1954). Metachromasia in the nervous system. $J$. Neuropath. exp. Neurol., 13, 161-167.

- , and Montagna, W. (1952). Histochemical studies of the myelin sheath and its fragmentation products during Wallerian (secondary) degeneration. I. Lipids. J. comp. Neurol., 97, 211-239.

_ and regeneration. II. Histochemistry. Ibid., 105, 333-353.

Pearse, A. G. E. (1960). Histochemistry, 2nd ed., p. 248. Churchill, London.

Russell, D. S., and Rubinstein, L. J. (1963). Pathology of Tumours o the Nervous System, 2nd ed., p. 128. Arnold, L ondon.

Singh, M., and Bachhawat, B. K. (1965). The distribution and variation with age of different uronic acid-containing mucopolysaccharides in brain. J. Neurochem., 12, 519-525.

Smith, M. C. (1949). Metachromatic bodies in the brain. J. Neurol. Neurosurg. Psychiat., 12, 100-110.

Spicer, S. S., Leppi, T. J., and Stoward, P. J. (1965). Suggestions for a histochemical terminology of carbohydrate-rich tissue components. J. Histochem. Cytochem., 13, 599-603.

Szabo, M. M., and Roboz-Einstein, E. (1962). Acidic polysaccharides in the central nervous system. Arch. Biochem., 98, 406-412.

Ungar, H., Hine, C. H., Kodama, J. K., and Anderson, H. H. (1955). Neuropathology of rats experimentally poisoned with ptertiary-butyltoluene. Arch. Path., 60, 139-149.

Wislocki, G. B., and Singer, M. (1950). The basophilic and metachromatic staining of myelin sheaths and its possible association with a sulfatide. J. comp. Neurol., 92, 71-91.

Wolman, M. (1956a). The mechanism of the Marchi type of methods for visualizing degenerating myelin. Model experiments with pure compounds. J. Histochem. Cytochem., 4, 195-199.

(1956b). Study of the early changes occurring in degenerating myelin. Neurology (Minneap.), 6, 636-639.

(1957). Histochemical study of changes occurring during the degeneration of myelin. J. Neurochem., 1, 370-376. 
(1960). The 'grape-like bodies' of the central nervous system. Confin. neurol. (Basel). 20, 36-44.

(1961). Differential staining of acidic tissue components by the improved Bi-Col method. Stain Technol., 36, 21-25.
- and Hestrin-Lerner, S. (1960). A histochemical contribution to the study of the molecular morphology of myelin sheath. J. Neurochem., 5, 114-120.

Young, I. J., and Abood, L. G. (1960). Histological demonstration of hyaluronic acid in the central nervous system. Ibid., 6, 89-94.

\section{The October 1967 Issue}

\section{THE OCTOBER 1967 ISSUE CONTAINS THE FOLLOWING PAPERS}

\author{
Some neuro-ophthalmological observations C. MILLER \\ FISHER
}

Median and ulnar neuropathy in the guinea-pig PAMELA M. FULLERTON and R. W. GILLIATT

Quantitative electromyography using automatic analysis: studies in healthy subjects and patients with primary muscle disease A. L. ROSE and R. G. WILLISON

Enzymes of the glycogen cycle and glycolysis in various human neuromuscular disorders SALVATORE DI MAURO, CORRADO ANGELINI, and CLAUDIA CATANI

Studies of the carrier state in the Duchenne type of muscular dystrophy Part I Effect of exercise on serum creatine kinase activity' PETER HUDGSON, DAVID GARDNERMEDWIN, R. J. T. PENNINGTON, and JOHN N. WALTON

Phrenic nerve conduction in man J. NEWSOM DAvis

Excitability of motor neurones in spinal shock in man E. DIAMANTOPOULOS and P. ZANDER OLSEN

The relation between chronic polyneuropathy and osteosclerotic myeloma J. B. MORLEY and A. C. SCHWLEGER
Phaeochromocytoma and cerebellar haemangioblastoma R. D. ILLINGWORTH

Spinal cord embolism LIONEL WOLMAN and PETER BRADSHAW

Hereditary cataplexy JO-ANN M. GELARDI and JASON w. BROWN

Longitudinal movement of radioiodinated albumin within extravascular spaces of peripheral nerves following three systems of experimental trauma ROSS MELLICK and J. B. CAVANAGH

Combined degeneration of the spinal cord due to deficiency of alimentary vitamin $B_{12} A$. VERJAAL and $A$. $H$. c. C. TIMMERMANS-VAN DEN BOS

Tachistoscopic number estimation in patients with unilateral cerebral lesions ELIZABETH $K$. WARRINGTON and MERLE JAMES

\section{Book Reviews}

Copies are still available and may be obtained from the PUBLISHING MANAGER, BRITISH MEDICAL ASSOCIATION, TAVISTOCK SQUARE, W.C.1, price, 18s. 6D. 